\title{
Bacterial Diseases of Crops: Epidemiology, Symptoms and Management
}

\author{
Abha Saxena*, Deepti Rai, Anup Kalra and Mohan Ji Saxena \\ Ayurvet Research Foundation, \\ Unit No. 101-103 $1^{\text {st }}$ floor Km trade tower, Plot no.H-3, Sector -14, \\ Kaushambi, Ghaziabad-201010 (U.P.) \\ *Corresponding author
}

\begin{abstract}
A B S T R A C T
Plants are the source of the air we breathe and most of the food we eat, yet we often don't ponder about keeping them healthy. This can have disturbing results. FAO estimates that up to $40 \%$ of food crops are lost due to plant pests and diseases annually. This leaves millions of people without enough food to eat and seriously damages agriculture - the primary source of income for rural poor communities. Plant health is increasingly under threat. Climate change and human activities, have altered ecosystems, reducing biodiversity and creating new niches where pests can thrive. At the same time, international travel and trade has tripled in volume in the last decade and can quickly spread pests and diseases around the world causing great damage to native plants and the environment. Protecting plants from pests and diseases is far more cost effective than dealing with full-blown plant health emergencies. Plant pests and diseases are often impossible to eradicate once they have established themselves and managing them is time consuming and expensive. Prevention is critical to avoiding the devastating impact of pests and diseases on agriculture, livelihoods and food security and many of us have a role to play.
\end{abstract}

Keywords

Bacterial diseases, Epidemiology, Symptoms and management

Article Info

Accepted:

18 May 2020

Available Online:

10 June 2020

\section{Introduction}

Most of plant pathogenic bacteria are rod shaped; the only exceptions are those belonging to genus Streptomyces which are filamentous. The cell walls of most species are enveloped with slimy substance, which in case of forming the thicker layer is called a capsule. The capsule slimes facilitate surviving of bacteria the unfavorable conditions, e.g. dryness and protecting them against deleterious factors. Most of bacteria produce out of the cell delicate flagella, which are filamentous structures build of proteins. Flagella are significantly longer than bacterial cells; in some species only one flagellum occurs (monotrichous flagellation), in others flagella are located on both ends of cell (lophotrichous), there are also bacteria flagellated at various places on cell 
(peritrichous). When single cell multiplies on artificial agar media, it produces the colony. The shape and size of colonies of various bacterial species vary and constitute an important feature helping their identification. The colonies can be flat, raised or wrinkled, circular or oval, shiny or mat. The colony colour of most species is whitish or greyish, sometimes yellowish.

The bacterial proteins play protective, nutritional and transportation functions. In cytoplasm nucleoid (chromosome) built of deoxyribonucleic acid (DNA) is located. Moreover, autonomic DNA structures called plasmids are often present. The plasmid genes are responsible for various traits of bacteria, like synthesis of toxins and other compounds related to their pathogenicity, as well as the resistance to unfavorable environmental conditions. Some of gram positive bacteria produce endospores, which help them survive unfavourable conditions (Billing, 1987; Agrios, 1997; Sobiczewski, Schollenberger, 2002; Kryczynski et al., 2002; Janse, 2005).

\section{Epidemiology}

Plant pathogenic bacteria are heterotrophic organisms, which can develop on host plants as parasites. They are not able to penetrate directly plant tissue. Infection usually occurs through natural openings like stomata, hydatodes, nectaroides as well as injures of various origin. The important places of infection appeared to be leaf scars. (Zemdirbyste Agriculture, Vol 95, no.3 (2008) p151-157)

\section{Major Bacterial diseases in food crops}

Listing below few important food plant's disease:

\section{Rice}

Rice (Oryza sativa L) is an important cereal crop grown in different countries of the world. In India, during 2018-19 the total production of Rice was 283.3MT. (Agribusiness, New Delhi Published on June 03, 2019). Out of 70 diseases known to attack the crop, 11 are of bacterial origin. These diseases are grouped into seedling, foliar, leaf sheath and grain and culm and root disease.

\section{Seedling diseases}

\section{Seedling blight}

Seedling blight is a secondary syndrome associated with foot and root rot diseases. It is common in Japan, and India.

\section{Symptoms}

Early symptoms are characterized by a basal chlorosis and withering of the second or third leaves. Infected seedlings later become reddish brown and desiccated but do not exhibit a soft rot. With severe infection, root growth is retarded and seedlings easily lodge (Fig.1).

\section{Causal organism}

The disease is caused by Pseudomonas plantarii. The bacterium is a Gram-negative, non-spore forming, non-encapsulated rod, with one to three polar flagella. P. plantarii produces a compound called tropolone, which is responsible for the retardation of root growth and leaf chlorosis of infected rice seedlings (Azegami et al., 1987).

\section{Management}

The application of iron compounds suppresses seedling blight, because the production of tropolone is inhibited in the presence of iron. Athionine producing gene from oat, coding for antimicrobial activity, when transferred to rice by biotechnological intervention, conferred resistance against the pathogen. 


\section{Bacterial brown stripe}

Bacterial Brown Stripe also in known a bacterial stripe, occurs in upland and wet land nurseries as well as in nursery boxes. Although it is widely distributed in the rice growing countries (Shakya et al., 1985), it does not cause much damage to production.

\section{Symptoms}

The symptoms of the disease in the seedling stage were divided into four types, viz, inhibition of germination, brown stripes occurring interveinally or along the midrib or leaf margins, curving of a sheath and abnormal elongation of mesocotyl (Fig.2). After the infected seedlings were transplanted to paddy fields, symptoms were masked. Natural occurrence of the disease was not seen after the tillering stage, except for the case where rice plants were submerged in the water by flood (Kadota and Ohuchi, 1983).

\section{Causal organism}

Bacterial brown stripe is caused by both Pseudomonas avenae and $P$. syringaepv. panici. P. avenae is a Gram-negative, nonspore forming, non-encapsulated rodwith one or two flagella. $P$. syrinage $p v$. panici, is also a Gram-negative, spore forming, nonencapsulated rod (Shakya et al., 1985)

\section{Management}

Dry heat treatment at $65^{\circ} \mathrm{C}$ for 6 days can eliminate the pathogen from seeds (Zeigler and Alvarez, 1988). In nursery boxes, spraying of Kasugamycin can control the pathogen.

Foliar diseases: Through Leaf surface

\section{Bacterial blight}

\section{Distribution}

Bacterial blight is one of the most devastating diseases of rice worldwide and is found both in tropical and temperate regions. Common in India and Bangladesh

\section{Symptoms}

There are three main symptoms caused by bacterial blight- leaf blight, wilt and yellow leaf or pale yellow. Leaf blight, the most common syndrome, generally occurs from the maximum tillering stage onward. It begins as water-soaked stripes on the leaf blades. The stripes increase in length and width, become yellow and then white, and may coalesce to cover the entire leaf blade. Drops of bacterial exudates may be observed on young lesions. Older infected leaves may appear grayish from the growth of saprophytic fungi. Small, circular lesions with water-soaked margins may also form on the glumes with severe infections. Infected plants produce fewer and lighter grains and the grain is of poor quality. The wilt syndrome, known as 'Kresek' is the most destructive manifestation of the disease found between the temperature $28^{\circ} \mathrm{C}$ and $34^{\circ} \mathrm{C}$. It occurs in the tropics from the seedlings to the early tillering stage. Leaves of infected plants wilt and roll up, turning grayish green. The leaves then turn yellow to straw-colored and entire plant generally dies. Plants that do survive are stunted and yellowish. Total crop failure is not uncommon with Kresek. In the tropics, yellow leaf or pale yellow syndrome is associated with bacterial blight (Fig. 3). The youngest leaf of the plant becomes uniformly pale yellow or has a broad yellow stripe. The bacteria are not present in the leaf itself but can be found in the internodes and crowns of affected stems (Saha et al., 2015). 
Causal Organism - Xanthomonas oryzae

\section{Management}

Management of bacterial blight, comprises ofi) use of host resistance ii) modification in cultural practices iii) biological control iv) use of natural products or botanicals extracts and v) use of conventional and non-conventional chemicals.

\section{Host resistance}

Genetic resistance is the most effective, practical and economic method of disease management. Considerable emphasis is being given on identification and incorporation of bacterial blight resistant gene donors in commercial cultivars using conventional breeding methods and molecular approaches

\section{Bacterial Leaf streak}

\section{Distribution}

The disease is widely distributed in tropical Asia and in West Africa in both lowland and upland rice growing areas. This disease is common in India.

\section{Symptoms}

The disease can occur at any growth stage and initially appears as small as interveinal, water soaked streaks. The streaks are at first dark green and later become translucent. The streaks enlarge and coalesce and eventually become light brown (Fig.4). Numerous tiny yellow beads of bacterial excaudate are common, covers the surface on lesions. Eventually, entire leaves turn brown and then grayish white and die. According to Shekhawat and Srivastava (1972) infection of florets and seeds results in brown or black discoloration and death of ovary, stamens and endosperm and browning of glumes. Seeds fail to mature but the rachis do not show any symptoms.

\section{Causal organism}

The disease is caused by Xanthomonas oryzae pv. oryzicola. The bacterium is a gramnegative, non-spore forming rod with a single polar flagellum.

\section{Management}

According to Shekhawat and Srivastava (1972), since the disease is seed-borne, seed treatment i.e overnight soaking of seeds in $0.025 \%$ streptocycline solution and hot water treatment at $52^{\circ} \mathrm{C}$ for 30 minutes are effective in eradicating seed infection. They have also reported that the sprays of Vitavax at 0.15$0.3 \%$ are effective in preventing infection and lesion development. In India IR-20, Krishna and Jagannath have shown good tolerance to the disease.

\section{Halo blight}

Halo blight, was first reported in 1985 in Japan.

\section{Causal organism}

Pseudomonas syringae

\section{Symptoms}

The disease is characterized by circular, pale green to yellowish brown lesions (Fig.5), 2-10 um in diameter on leaf blades. The lesions are surrounded by a distinct halo and have a dark brown spot or stripe in the center. The lesions may coalesce to form large blotches. The disease has not caused serious damage to date (Kuwata, 1985)

\section{Leaf sheath and grain rot}

\section{Sheath brown rot}

Sheath brown rot has been reported inAsia, South America, Central Africaand Madagascar. 


\section{Symptoms}

On seedlings, a systemic discoloration of the leaf sheath occurs, which may spread to the midrib or veins of the leaves. On the mature plants, symptoms typically occur on the flag leaf sheath from the booting to heading stage, become dry and the panicle withers. Glumes of panicles emerging from infected sheaths exhibit watersoaked lesions that turn light brown. Grains of infected panicles are discolored, deformed or empty (Zeigler and Alvarez, 1987, 1990).

\section{Causal organism}

The disease is caused by Pseudomonas fuscovaginae, which is a Gram negative, nonspore forming rod, with one to four polar flagella (Tanii et al., 1976).

\section{Management}

Use of clean seed or seed treated with dry heat at $64^{\circ} \mathrm{C}$ for 6 days is important in management of sheath brown rot. Antibiotics such as streptpmycin, alone or in combination with oxytetracycline also, can effectively manage sheath brown rot if applied at or a few days after panicle emergence.

\section{Sheath rot}

Sheath rot caused by Pseudomonas syringae $p v$ syringae (syn $\mathrm{P}$. oryzicola) is identicalin symptomatology to sheath brown rot caused by $P$. fuscovaginae. It is the only reported sheathrot pathogen of rice in Chile and has been reported from Asia, Australia and Hungary (Zeigler and Alvarez, 1990).

\section{Grain rot}

Grain rot occurs in Japan, Korea and Taiwan. The disease is manifested as a grain rot of mature plants in the field and also as a seedling rot (Chien et al., 1983).

\section{Symptoms}

On seedlings, symptoms consist of abrown, water-soaked soft rot of leaf sheaths accompanied by wilting or soft rot of the leaves. On the panicle grains are shrunken and pale green, becoming dirty yellow to brown and dry (Fig.7). A brown margin between the infected and healthy parts of the grain is a diagnostic feature of the disease. Amild rot of the flag leaf sheath or the flag leaf sheath collar occurs (Zeigler and Alvarez, 1990).

\section{Causal organism}

Grain rot is caused by Pseudomonas glumae. The bacterium is a Gram negative rod with one to three polar flagella.

\section{Management}

The pathogen may be eradicated fromsmall seed samples with dry heat treatment of $65^{\circ}$ Cfor 6 days. Pre-treatment of rice seeds with a high concentration of $(1010 \mathrm{cfu} / \mathrm{ml})$ of the avirulent strain of P.glumae is the most effective method for reducing the incidence.

(Ref- https://www.plantdiseases.org/grain-rotrice)

\section{Bacterial palea browning}

The disease occurs in Japan and affects grain quality. Disease incidence as high as $32 \%$ and reduction in 1000 seed weight by as much as15\% have been reported (Azegami et al., 1983).

\section{Symptoms}

Symptoms usually first appear at early. Initially, light brown, water soaked lesions occur on the lemma or palea. The lesions then turn dark brown, The discoloration occurs most frequently on the palea. Infected 
panicles have more immature grains and lighter grains at harvest, and infected grains become brown after milling.

\section{Causal organism}

The bacterium responsible for the disease is Erwnia herbicola. It is Gram negative, and fermentative, with peritrichous flagella.

\section{Management}

No management for the disease is available.

\section{Culm and root disease}

\section{Bacterial foot rot}

Foot rot occurs in India, Bangladesh, Korea and the Philippines (Goto, 1979).

\section{Symptoms}

Leaf sheaths of infected plants typically exhibit a dark brown decay, and attached leaves turn yellow and wilt. Infection often begins in the ligules. The nodes, culms, and crown also become rotted, and infected tillers can easily be detached from the crown. Infected culms and internodes turnblack (Fig.8). Roots attached to infected nodes decay and fall off. Bacterial ooze may be present inside theculms and infected plants have an unpleasant odor. In some cases, the young leaves of tillers that show no sheath browning may wilt as a result of systemic infection of the crown alone.

\section{Causal organism}

The disease is caused by Erwinia chrysanthemi. The bacterium is a Gramnegative rod with four to six peritrichous flagella.

\section{Management}

No management for the disease is available

\section{Wheat}

\section{Bacterial leaf streak}

Bacterial leaf streak (BLS) of Wheat, also known as bacterial leaf stripe, is caused by Xanthomonas translucens. The disease, called black chaff when on the glumes, is seed-borne and a constraint for international germplasm exchange

\section{Symptoms}

Leaf streak and black chaff Typical symptoms on the leaf consist of elongated, light brown lesions, several centimeters long, which are initially distinct but later coalesce to cover larger solid areas. Early symptoms are characterized by translucent stripes that are easily seen under incident light (Fig.9). Initially lesions are water-soaked and produce honey-like exudates under humid conditions. If undisturbed, the exudates harden into yellowish, resinous granules studding the surface of the lesions and are easily detachable. Frequently, these droplets coalesce when there is dew, rain or guttation water to form conspicuous milky drops that may later spread over the leaf surface and dry down as thin, greyish, almost transparent flakes. In commercial wheat fields, particularly without sprinkler irrigation, lesions with no exudate can be observed this makes it difficult to identify the cause of the symptoms without isolating the pathogen.

\section{Causal Organism - Xanthomonas translucens}

\section{Management}

Discarding infected seed prior to planting should be the primary control measure, since sowing pathogen-free seed is the first logical step in avoiding an outbreak. Foundation seed should be multiplied in disease-free areas where climatic conditions are unfavourable 
for the development of epidemics. Seed should be disinfected before sowing even if currently available seed treatments are not fully satisfactory. Wheat growers should keep in mind that dry environments do not hamper the multiplication of $X$. t. pv. undulosa once it is in the leaf and that temperature has a major effect on pathogen multiplication in leaf tissue. The most economical and environmentally friendly way of controlling BLS is through genetic resistance.

(Ref- https://extension.umn.edu/small-grainspest-management/bacterial-leaf-streak-andblack-chaff-small-grains)

\section{Bacterial leaf blight}

\section{Description}

The bacterium, Pseudomonas syringae $p v$. syringae, causes a disease favored by cool to mild temperatures and high relative humidity. The bacterium is in seeds, soil, plant residues, and water and may spread by infected seed or water. Severe epidemics are periodic in irrigated heat. Other cereals may be affected, including oats, rye, and triticale.

\section{Causal organism}

The bacterium, Pseudomonas syringae pv. syringae, causes a disease

\section{Symptoms}

Generally, after boot stage, water-soaked spots develop which expand and progress from gray-green to tan-white. Spots may coalesce into irregular streaks or blotches, and entire leaves may turn brown and die while heads and glumes remain symptomless. Slimy droplets may develop on leaves in wet weather (Fig.10).

\section{Cultural measures}

Bacterial diseases are difficult to control once symptoms are evident in the field.

Avoid the disease by planting pathogen-free seed.

Irrigate less frequently to keep relative humidity lower.

Seed treatment Du-Ter and Captan, dissolved in dichloromethane and Blitox, Terramycin and Benlate dissolved in acetone were effective in elimination of the pathogen from seed.

Spray Streptocycline at $0.3 \mathrm{~g}$ in 10 liter of water has significant effect in controlling the initial infection.

(Ref- http://agropedia.iitk.ac.in/content/ bacterial-diseases)

\section{Basal glume rot}

\section{Description}

The leaves, culms, and spikes of wheat can be infected.

\section{Casual organism}

\section{Pseudomonas syringae pv. atrofaciens}

\section{Symptoms}

Infections begin as small, dark green, watersoaked lesions that turn dark brown to blackish in colour. On the spikelets, lesions generally start at the base of the glume and may eventually extend over the entire glume. Diseased glumes have a translucent appearance when held toward the light. Dark brown to black discoloration occurs with age (Fig.11). The disease may spread to the rachis, and lesions may also develop on the kernels. Under wet or humid conditions, whitish grey bacterial ooze may be present. Stem infections result in dark discoloration of the stem; leaf infections result in small, irregular, water-soaked lesions. Symptoms can be confused with those of other bacterial diseases, genetic melanism (false black chaff), septoria blotch, and frost damage 


\section{Management}

Grow resistant varieties.

Follow field sanitation.

Use certified seeds.

Avoid late sowing.

Use solarisation technique for seed

Treatment that is during hot summer months in morning hours the seed is soaked in cold water and kept in hot sun from 8.00 AM to 12.00 noon and then dried in the afternoon, precautions should be taken so that there is no damage to the viability of the seed.

Up-root the affected plants before ear emergence if they are affected with disease.

(Ref- http://agropedia.iitk.ac.in/content/basalglume-rot)

\section{Horticulture crops}

Common bacterial diseases of vegetable crops are provided in the table below with some typical symptoms

\section{Other bacterial diseases of vegetables} include

Peppery leaf spot - Pseudomonas syringae pv. maculicola (brassicas)

Varnish spot - Pseudomonas spp. (lettuce)

Corky root -Rhizomonas suberifaciens (lettuce);

Angular leaf spot $-P$. syringae $p v$. lachrymans (cucurbits);

Bacterial pith necrosis - Pseudomonas corrugata and other bacteria (tomatoes);

Common bacterial blight -Xanthomonas campestris pv. phaseoli (beans)

Halo blight -Pseudomonas syringae $p v$. phaseolicola (beans)

Black leg -Erwinia carotovora $p v$. atroseptica (potatoes).

\section{Management}

Disease management strategies aim to favour the host plant's growth and development while attacking vulnerable stages in the lifecycle of the pathogen to prevent or restrict its development. The key means of bacterial disease management include:

Exclusion or eradication of the pathogen (quarantine and use of pathogen-tested seeds and propagated materials)

Use of clean transplants

Monitor crops regularly and use predictive models

Reduce the pathogen levels by crop rotation

Remove weeds and incorporate crop residues that can host the disease

Protect the host plant by using resistant plant varieties

Minimise mechanical damage to crops and damage by insect pests

Avoid working in crops when they are wet

Spray with a registered bactericide when weather conditions favour disease development to prevent infection

Understand chemical resistance and rotation of chemical groups

If the plants are already infected, isolate and destroy them and prune infected leaves, but avoid excessive handling of diseased plants; if the disease is systemic and has spread throughout the plant, the plant cannot recover and should be destroyed (burning or burying)

Use correct temperatures and packing conditions during transport and storage.

(Ref- https://ausveg.com.au/biosecurityagrichemical/crop-protection/overviewpests-diseases-disorders/bacterialdiseases)

In conclusion, bacterial diseases continue to intrigue the plant pathologists in its management as chemical control is really hard to devise. Specific bactericides are gradually coming to the fore but it has to be 
coupled with cultural, breeding and new approaches of the disease management. biotechnological techniques so as to usher in

Table.1 Common bacterial diseases of vegetable crops are provided in the table below with some typical symptoms

\begin{tabular}{|c|c|c|c|}
\hline Bacterial disease & $\begin{array}{l}\text { Factors conducive to } \\
\text { spread }\end{array}$ & Crops affected & Symptoms \\
\hline $\begin{array}{c}\text { Black rot } \\
\text { (Xanthomonas } \\
\text { campestris pv. } \\
\text { campestris) }\end{array}$ & Warm, wet conditions. & Brassicas. & $\begin{array}{l}\text { Light-brown to yellow V- } \\
\text { shaped lesions on the leaf, } \\
\text { which become brittle and dry } \\
\text { with age. } \\
\text { Vein blackening with the } \\
\text { necrotic area. }\end{array}$ \\
\hline $\begin{array}{l}\text { Bacterial canker } \\
\text { (Clavibacter } \\
\text { michiganensis pv. } \\
\text { michiganensis) }\end{array}$ & $\begin{array}{l}\text { Moderate temperatures } \\
\text { and high humidity. }\end{array}$ & $\begin{array}{l}\text { Tomato; capsicum; } \\
\text { chilli }\end{array}$ & $\begin{array}{l}\text { Seedlings may die and older } \\
\text { plants may wilt and die } \\
\text { eventually. Older plants have } \\
\text { leaves that turn yellow and wilt } \\
\text { only on one side. } \\
\text { Cankers on stems and fruit. } \\
\text { Tissue inside stems becomes } \\
\text { discoloured. }\end{array}$ \\
\hline $\begin{array}{c}\text { Bacterial soft rot } \\
\text { (Pseudomonas spp., } \\
\text { Erwinia spp.) }\end{array}$ & Warm, wet conditions. & $\begin{array}{l}\text { Wide range of } \\
\text { vegetables, including } \\
\text { lettuce; brassicas; } \\
\text { cucurbits; tomato; } \\
\text { capsicum; potato; } \\
\text { sweet potato; carrots; } \\
\text { herbs. }\end{array}$ & $\begin{array}{l}\text { Wet, slimy, soft rot that affects } \\
\text { any part of vegetable crops } \\
\text { including heads, curds, edible } \\
\text { roots, stems and leaves. } \\
\text { May have a disagreeable } \\
\text { odour. }\end{array}$ \\
\hline $\begin{array}{c}\text { Bacterial leaf } \\
\text { spot/Bacterial spot } \\
\text { (Xanthomonas } \\
\text { campestris - various } \\
\text { strains) }\end{array}$ & $\begin{array}{l}\text { Overhead irrigation and } \\
\text { windy conditions. }\end{array}$ & $\begin{array}{l}\text { Range of vegetables } \\
\text { including lettuce; } \\
\text { cucurbits; tomato; } \\
\text { capsicum. }\end{array}$ & $\begin{array}{l}\text { Lettuce - Large brown to black } \\
\text { circular areas that start as small } \\
\text { translucent spots; usually on } \\
\text { outer leaves. } \\
\text { Tomatoes and capsicums - } \\
\text { Greasy spots on leaves and } \\
\text { stems that go from tan to black; } \\
\text { fruit may have circular spots } \\
\text { with central scab. } \\
\text { Cucurbits - Begin as small } \\
\text { water-soaked/greasy spots on } \\
\text { underside of leaves with } \\
\text { corresponding yellowing on } \\
\text { upper side; fruit may produce } \\
\text { light-brown ooze from water- }\end{array}$ \\
\hline
\end{tabular}




\begin{tabular}{|c|c|c|c|}
\hline & & & soaked markings. \\
\hline $\begin{array}{l}\text { Bacterial wilt } \\
\quad \text { (Ralstonia } \\
\text { solanacearum) }\end{array}$ & $\begin{array}{l}\text { High temperatures, high } \\
\text { soil moisture and poor } \\
\text { drainage. Once infection } \\
\text { has occurred, severity of } \\
\text { symptoms is increased } \\
\text { with hot and dry } \\
\text { conditions, which } \\
\text { facilitate wilting. }\end{array}$ & $\begin{array}{c}\text { Potato; tomato; } \\
\text { capsicum; eggplant. }\end{array}$ & $\begin{array}{l}\text { Wilting, yellowing and } \\
\text { stunting of plants but they may } \\
\text { wilt rapidly and die without } \\
\text { any spotting or yellowing } \\
\text { vascular tissue appears brown } \\
\text { and water-soaked } \\
\text { a white ooze appears when } \\
\text { pressure is applied to affected } \\
\text { tubers or stems. }\end{array}$ \\
\hline $\begin{array}{c}\text { Bacterial leaf } \\
\text { spot/Bacterial } \\
\text { spot/Bacterial } \\
\text { blight } \\
\text { (Pseudomonas } \\
\text { syringae - various } \\
\text { strains) }\end{array}$ & $\begin{array}{l}\text { Long periods of leaf } \\
\text { wetness. }\end{array}$ & $\begin{array}{l}\text { Beet; spring onions; } \\
\text { leeks; rocket; } \\
\text { coriander. }\end{array}$ & $\begin{array}{l}\text { Beet - irregular, round leaf } \\
\text { spots with a grey centre } \\
\text { surrounded by a purple margin. } \\
\text { Spring onions/shallots - pale } \\
\text { yellow to light-brown lesions } \\
\text { with a water-soaked } \\
\text { appearance around the margins } \\
\text { outer leaves wither and die and } \\
\text { youngest leaf turns lemon to } \\
\text { light-green. } \\
\text { Leeks - brown streaking on } \\
\text { the shank. }\end{array}$ \\
\hline $\begin{array}{l}\text { Bacterial blight } \\
\text { (Pseudomonas } \\
\text { syringae pv.pisi) }\end{array}$ & $\begin{array}{l}\text { Cool, wet, windy } \\
\text { conditions. }\end{array}$ & Peas. & $\begin{array}{l}\text { Water-soaked spots on leaves } \\
\text { and stipules which become } \\
\text { dark-brown and papery in } \\
\text { warm weather or black in cool } \\
\text { weather. } \\
\text { Water-soaked spots on pods } \\
\text { that become sunken and dark- } \\
\text { brown. }\end{array}$ \\
\hline $\begin{array}{l}\text { Bacterial speck } \\
\text { (Pseudomonas } \\
\text { syringae pv. } \\
\text { tomato) }\end{array}$ & $\begin{array}{c}\text { Humidity and overhead } \\
\text { irrigation. }\end{array}$ & Tomato. & $\begin{array}{l}\text { Small dark spots surrounded by } \\
\text { a yellow halo on leaves } \\
\text { dark raised specks on fruit. }\end{array}$ \\
\hline $\begin{array}{l}\text { Bacterial brown } \\
\text { spot (Pseudomonas } \\
\text { syringae pv. } \\
\text { syringae) }\end{array}$ & $\begin{array}{l}\text { Cool, wet, windy } \\
\text { conditions. }\end{array}$ & Beans. & $\begin{array}{l}\text { Tan to reddish-brown spots on } \\
\text { leaves. } \\
\text { Water-soaked spots on pods } \\
\text { which enlarge and become } \\
\text { sunken and tan with distinctive } \\
\text { reddish-brown margins. }\end{array}$ \\
\hline
\end{tabular}


Fig.1 Seedling blight of rice

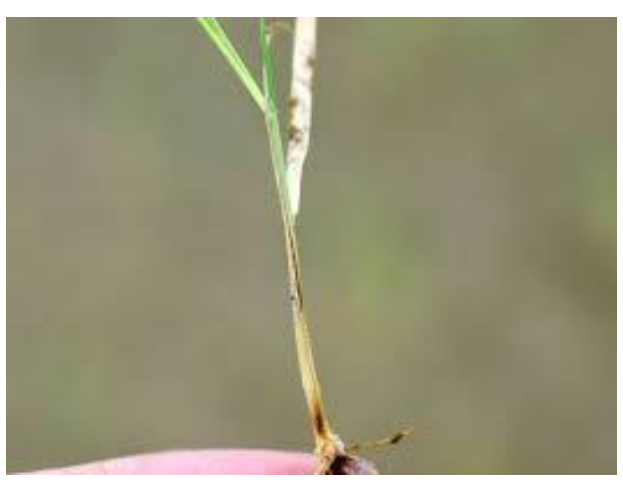

Fig.2 Bacterial brown stripe - rice

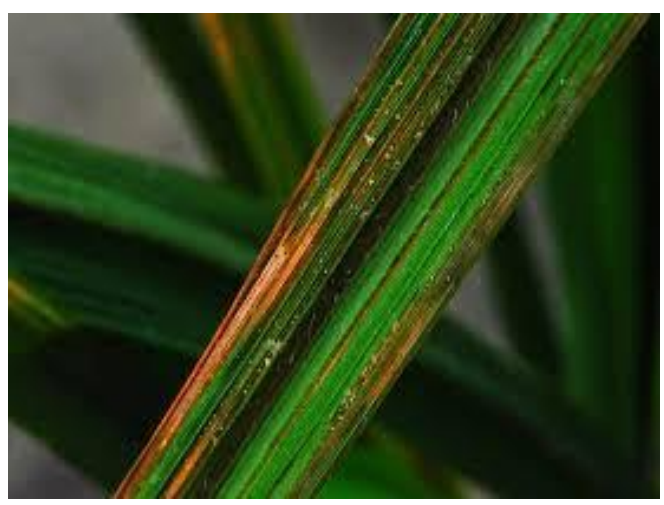

Fig.3 Bacterial blight of rice

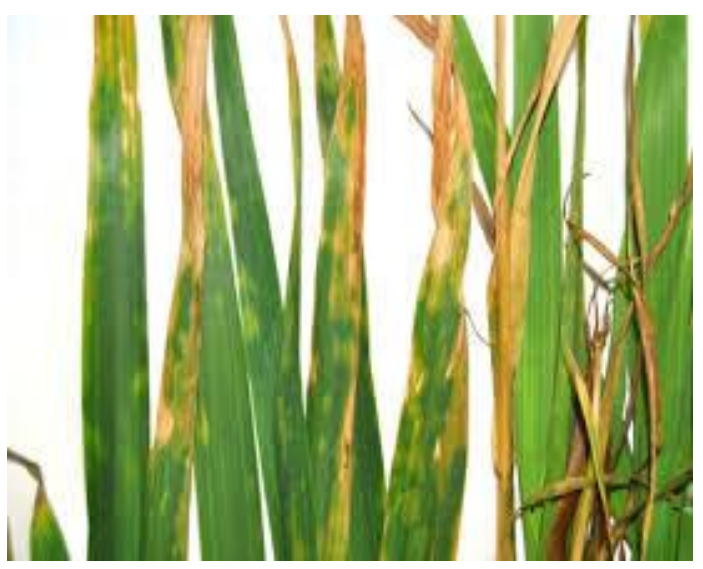


Fig.4 Bacterial leaf streak

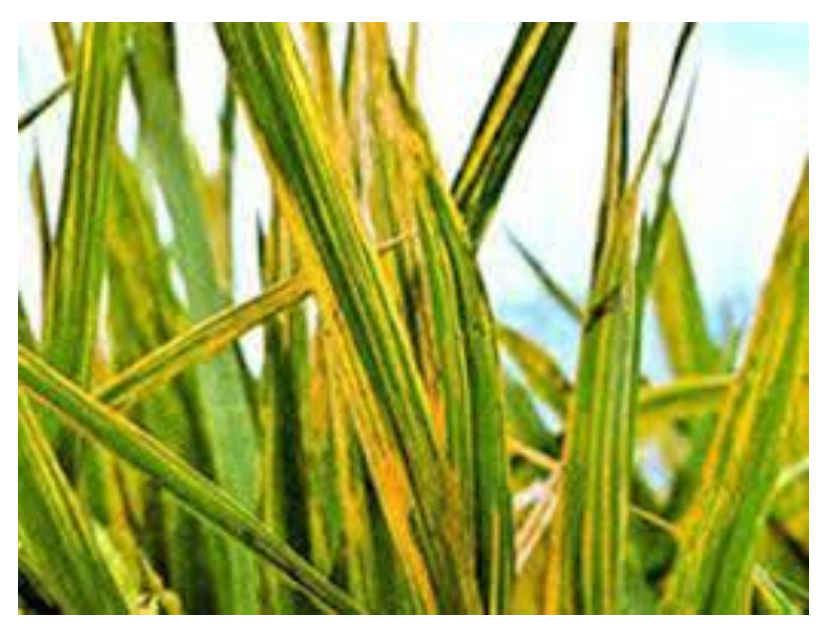

Fig.5 Halo blight

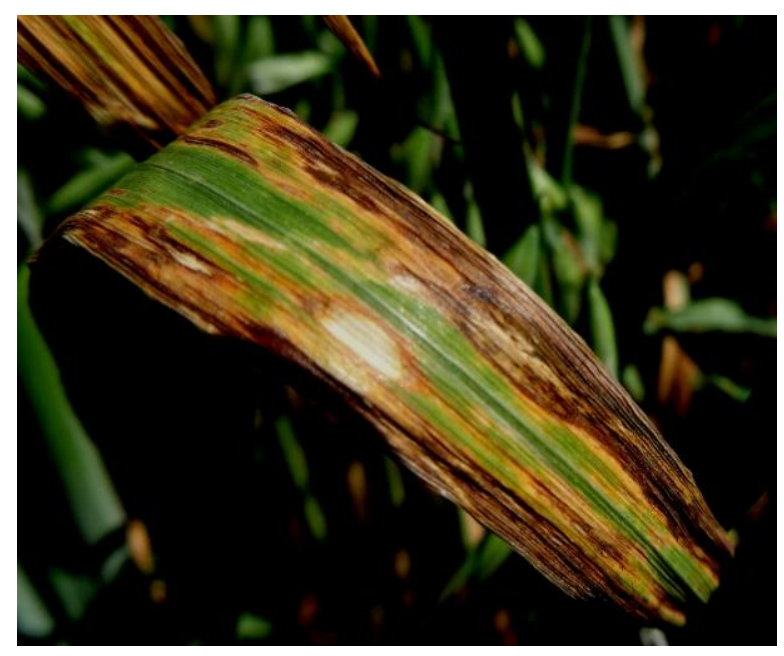

Fig.6 Sheath brown rot- rice

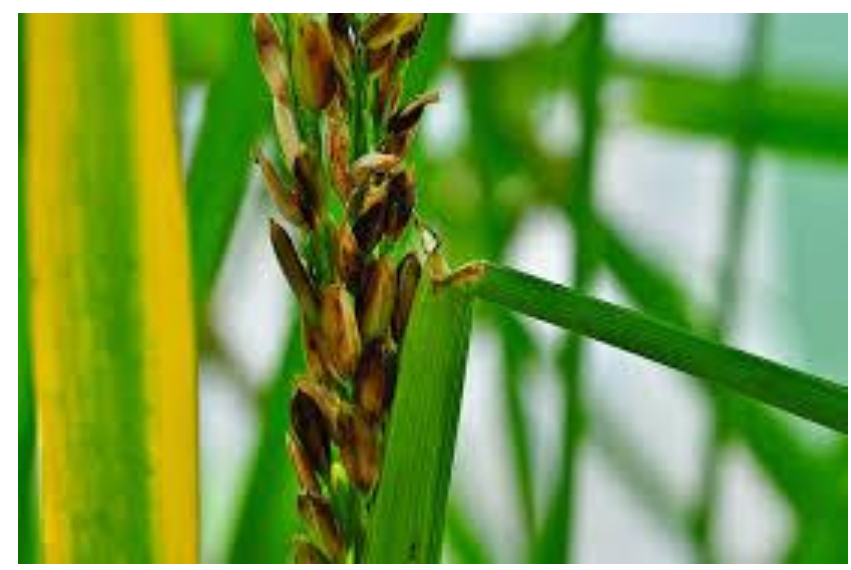


Fig.7 Grain rot of rice

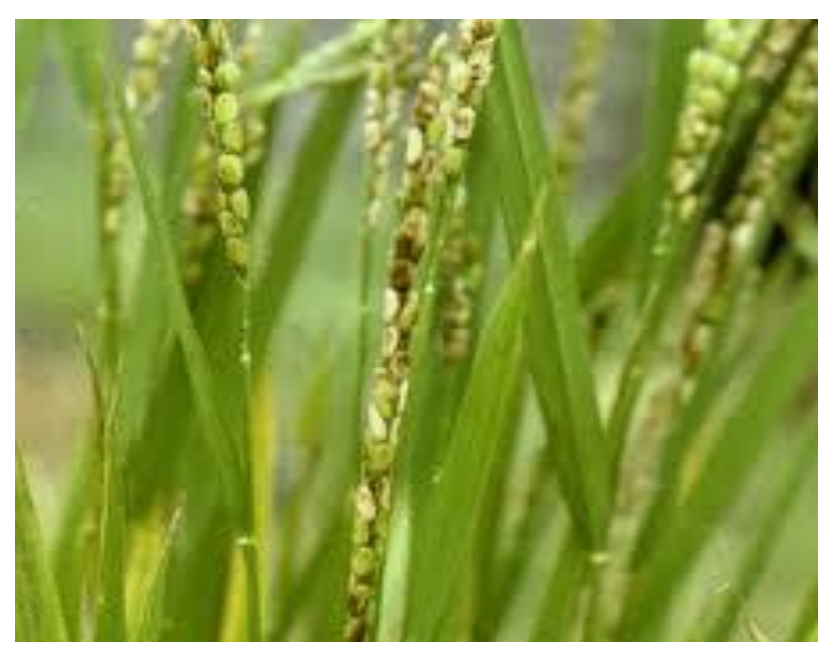

Fig.8 Bacterial foot rot - rice

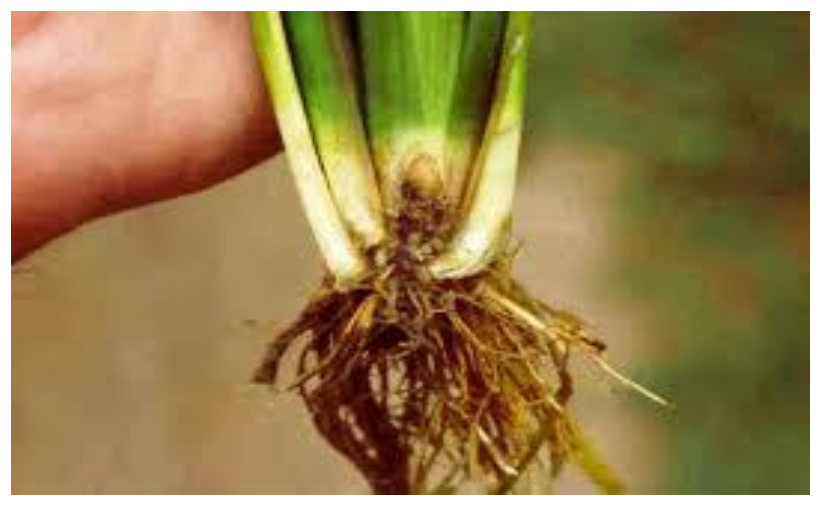

Fig.9 Bacterial leaf streak- wheat

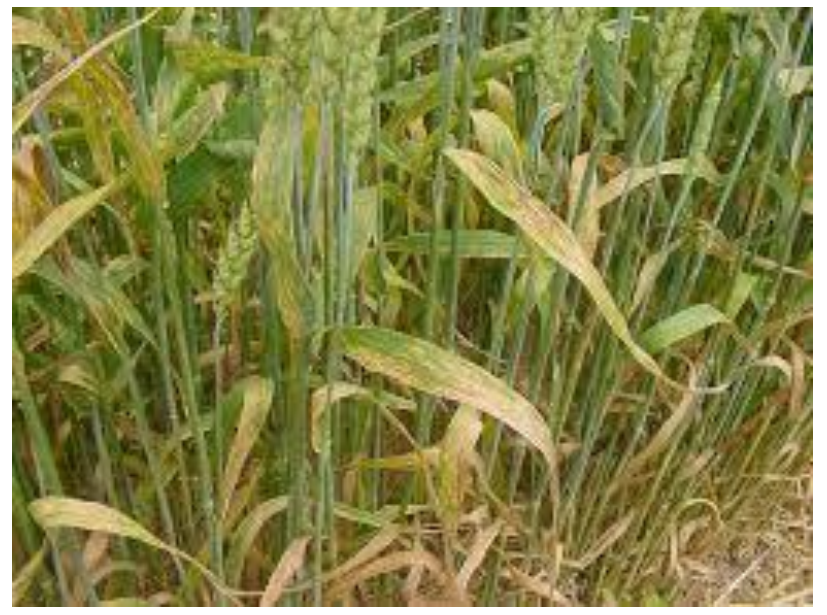


Fig.10 Bacterial leaf blight in wheat

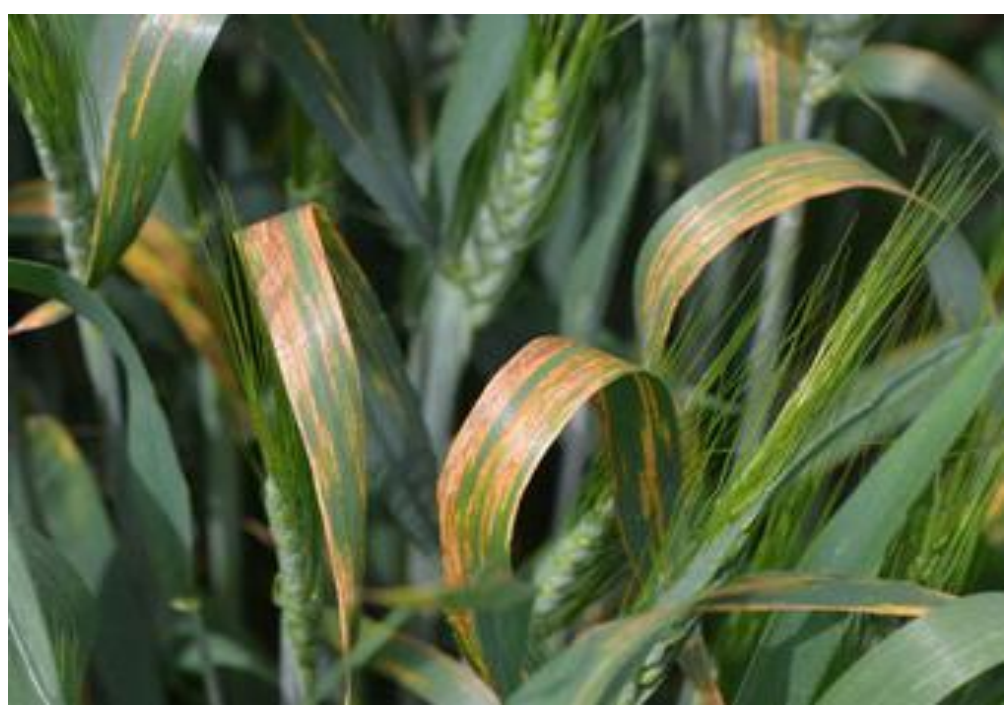

Fig.11 Basal glume rot in wheat

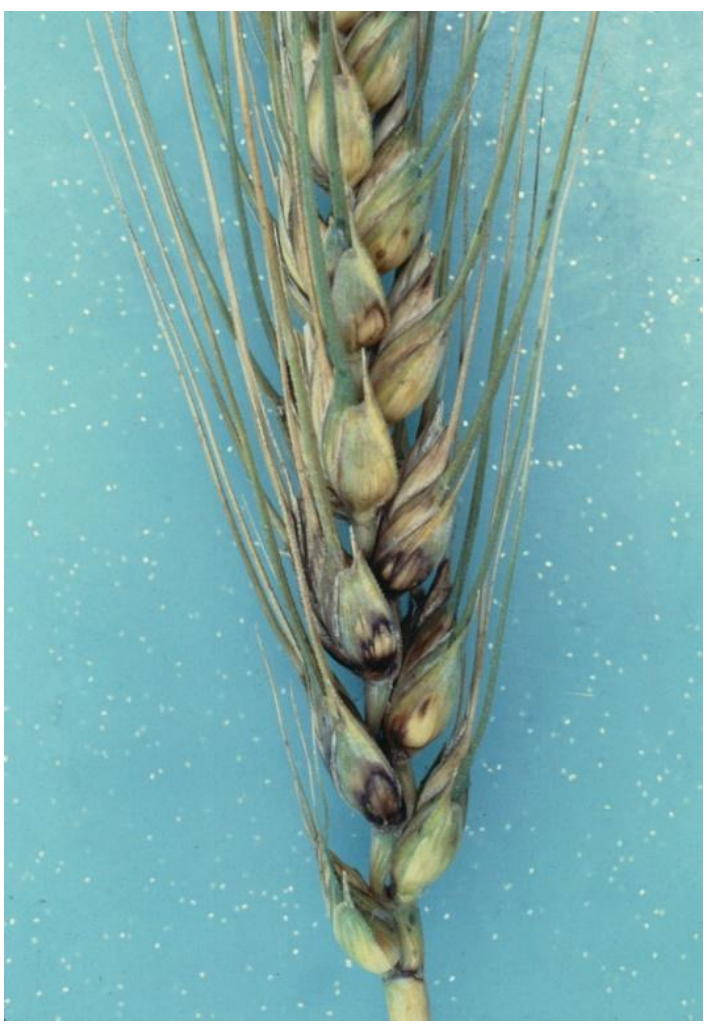




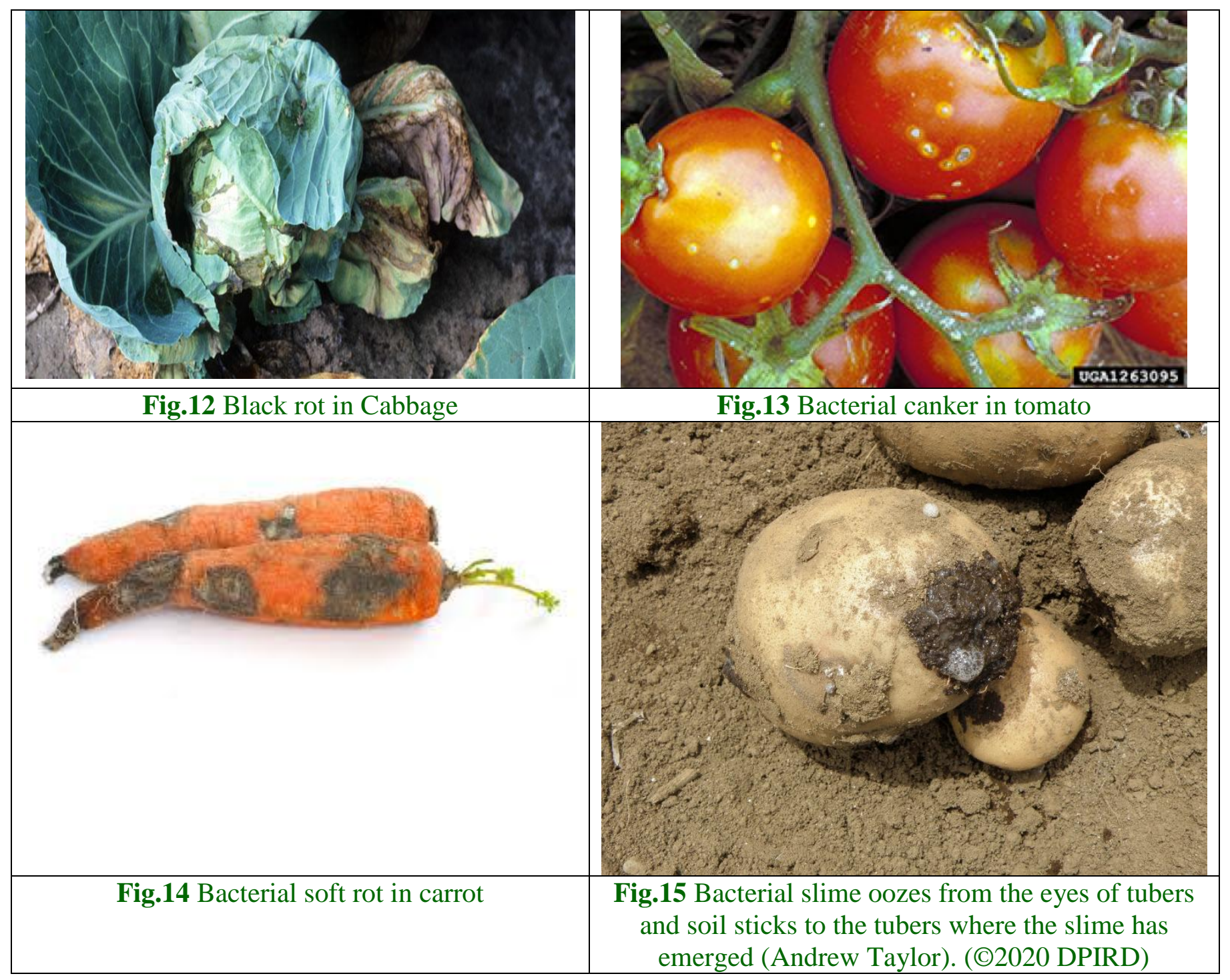

\section{Management}

Disease management strategies aim to favour the host plant's growth and development while attacking vulnerable stages in the lifecycle of the pathogen to prevent or restrict its development. The key means of bacterial disease management include:

Exclusion or eradication of the pathogen (quarantine and use of pathogentested seeds and propagated materials)

Use of clean transplants

Monitor crops regularly and use predictive models
Reduce the pathogen levels by crop rotation

Remove weeds and incorporate crop residues that can host the disease

Protect the host plant by using resistant plant varieties

Minimise mechanical damage to crops and damage by insect pests

Avoid working in crops when they are wet

Spray with a registered bactericide when weather conditions favour disease development to prevent infection

Understand chemical resistance and rotation of chemical groups

If the plants are already infected, isolate and destroy them and prune infected 
leaves, but avoid excessive handling of diseased plants; if the disease is systemic and has spread throughout the plant, the plant cannot recover and should be destroyed (burning or burying)

Use correct temperatures and packing conditions during transport and storage.

In conclusion, Bacterial diseases continue to intrigue the plant pathologists in its management as chemical control is really hard to devise. Specific bactericides are gradually coming to the fore but it has to be coupled with cultural, breeding and biotechnological techniques so as to usher in new approaches of the disease.

\section{References}

Agrios G. N. Plant Pathology. - Academic Press, 1997. - $635 \mathrm{p}$

Azegami K, Nishiyama K, Watanabe Y, Kadota I, Ohuchi A and Fukazawa C. Pseudomonas plantarii sp. nov., the causal organism of rice seedling blight, Int. J. Syst. Bacteriol. 1987; 37: 144-152

Billing E. Bacteria as Plant Pathogens. Aspects of Microbiology 14. / ed. Van Nostrand Reinhold. - Wokingham (UK), 1987. - 79 p.

Chien CC, Chang YC, Lao YM and Ou SH. Bacterial grain rot of rice A new disease in Taiwan, J. Agric. Res. China, 1983; 32: 360- 366.

Goto M. Dissemination of Erwinia chrysanthemi, the causal organism of bacterial foot rot of rice. Pl. Dis. Rep, 1979; 63: 100-103.

International year of plant Health, Food and Agriculture Organization of the United Nation, 2020.

Janse J. D. Phytobacteriology, principles and practice. - Wallingford: CABI Publishing, 2005. $-360 \mathrm{p}$.
Kryczyński S., Mańka M., Sobiczewski P. Słownikfitopatologiczny

(Phytopathological Dictionary, in Polish). - Warszawa: Hortpress, 2002. $179 \mathrm{p}$.

Kadota I and Ohuchi A. Symptoms of bacterial brown stripe of rice seedlings in nursery boxes, Ann. Phytopathol. Soc. Jpn. 1983; 49: 561-564.

Kuwata H, Pseudomonas syringae pv. oryzae pv. Nov, causal agent of bacterial halo blight of rice. Ann. Phytopathol. Soc. Jpn, 1985; 33: 111.

Sobiczewski P., Schollenberger M. Bakteryjne chorobyroślinogrodniczych. Podręcznik dlastudentów. (Bacterial diseases of horticultural plants - manual for students, in Polish). - PWRiL, Warszawa, 2002, p. 156-187

Shakya D, Vinther F and Mathur S, World wide distribution of bacterial stripe pathogen of rice identified as Pseudomonas avenae. Phytopathol Z., 1985; 114: 256-259.

Shekhawat GS and Srivastava DN, Control of bacterial leaf streak of rice. Ind. J. Agric. Sci. 1971; 41: 1098-1101.

Sujoy Saha, Ruchi Garg, Arunava Biswas and A.B. Rai, 2015: Bacterial Diseases of Rice: An Overview- Journal of Pure and Applied Microbiology, March 2015. Vol. 9(1), p. 725-736.

Tanii A, Miyajima K and Akita T, The sheath brown disease of rice plant and its causal bacterium. Pseudomonas fuscovaginae. Ann. Phytopathol. Soc. Jpn, 1976; 42: 540-548.

The Hindustan Business - Agribusiness, Agri Ministry projects record Rice output for 2018-2019, New Delhi June 03, 2019.

Zeigler RS and Alvarez E, Bacterial sheath of rice caused by Pseudomonas fuscovaginae in Latin America. Plant. Dis, 1987; 71 : 592-597.

Zeigler RS and Alvarez E, Characteristics of Pseudomonas spp. Causing grain 
discolouration and sheath rot of rice and associated pseudomonad epiphytes. Plant Dis. 1990; 74: 917-922

Zemdirbyste agriculture, Vol 95, no.3(2008) p151-157.

Ref- https://extension.umn.edu/small-grainspest-management/bacterial-leaf-streakand-black-chaff-small-grains)

Ref- http://agropedia.iitk.ac.in/content/bacteri al-diseases)

Ref- http://agropedia.iitk.ac.in/content/basalglume-rot)

Ref- $\quad$ https://ausveg.com.au/biosecurityagrichemical/crop-protection/overviewpests-diseases-disorders/bacterialdiseases

\section{How to cite this article:}

Abha Saxena, DeeptiRai, AnupKalra and Mohan Ji Saxena. 2020. Bacterial Diseases of Crops: Epidemiology, Symptoms and Management. Int.J.Curr.Microbiol.App.Sci. 9(06): 1483-1499. doi: https://doi.org/10.20546/ijcmas.2020.906.183

\begin{tabular}{|c|c|}
\hline Fig- 1 -Seedling Blight of Rice & $\begin{array}{l}\text { PUB- } 3117 \text { The LSU AgCenter is a statewide campus of the LSU } \\
\text { System and provides equal opportunities in programs and } \\
\text { employment }\end{array}$ \\
\hline Fig.2-Bacterial Brown Stripe - Rice & $\begin{array}{l}\text { Ref-http://www.knowledgebank.irri.org/training/fact-sheets/pest- } \\
\text { management/diseases/item/bacterial-leaf-streak }\end{array}$ \\
\hline Fig.3-Bacterial Blight of Rice & Ref- Online plant Clinic, Dept of Agriculture Govt.Of Kerala \\
\hline Fig.4- Bacterial Leaf Streak & $\begin{array}{l}\text { Ref- } \\
\text { http://www.cpsskerala.in/OPC/pages/riceDiseasebacleafstreak.jsp }\end{array}$ \\
\hline Fig. 5- Halo Blight & Ref- https://www.agric.wa.gov.au/mycrop/diagnosing-halo-blight \\
\hline Fig.6- Sheath Brown rot- Rice & $\begin{array}{l}\text { Ref- http://www.knowledgebank.irri.org/training/fact-sheets/pest- } \\
\text { management/diseases/item/bacterial-sheath-brown-rot }\end{array}$ \\
\hline Fig. 7- Grain rot of Rice & Ref- https://www.plantdiseases.org/grain-rot-rice \\
\hline Fig.8- Bacterial Foot Rot - Rice & Ref-https://www.lsuagcenter.com/topics/crops/rice/diseases/photos \\
\hline Fig.9- Bacterial Leaf Streak- Wheat & Ref- Internet source of Minnesota Wheat growers \\
\hline Fig 10.-Bacterial Leaf Blight in Wheat & Ref- http://agropedia.iitk.ac.in/content/bacterial-diseases \\
\hline Fig-11. Basal Glume rot in Wheat & Ref- http://agropedia.iitk.ac.in/content/basal-glume-rot \\
\hline Fig.12- Black rot in Cabbage & $\begin{array}{l}\text { Ref- https://www.growveg.com/plant-diseases/us-and- } \\
\text { canada/brassica-black-rot }\end{array}$ \\
\hline Fig.13- Bacterial canker in tomato & Ref- Educational material - University of Minnesota Extension \\
\hline Fig. 14- Bacterial soft rot in carrot & Ref- Greenlife crop protection-Africa \\
\hline $\begin{array}{l}\text { Fig.15- Bacterial slime oozes from the } \\
\text { eyes of tubers and soil sticks to the } \\
\text { tubers where the slime has emerged }\end{array}$ & (Andrew Taylor). (C2020 DPIRD) \\
\hline
\end{tabular}

